\title{
TEACHER'S USE OF CODE SWITCHING AND THEIR MOTIVATION IN ENGLISH CLASS
}

\author{
Paramytha Wijayanti. K.D, Suparno, Hefy Sulistyawati
}

\author{
English Education Department \\ Teacher Training and Education Faculty \\ Sebelas Maret University
}

Email: paramythawijayanti@ymail.com

\begin{abstract}
This research investigates the use of code-switching by the teacher in English class of one of junior high schools in Surakarta. The subject of this research is the English teacher and the students of three classes in grade VII. The focus of this research is the teacher's code-switching covering the types, reasons/motivations, and the functions of codeswitching. This research uses a qualitative method in the form of case study. Furthermore, the technique of analyzing data used in this research is interactive model consists of data reduction, data display, and conclusion/verification. The data in this research are teachers' utterances, students' utterances, and interview statements that are obtained from observation and interview. The implementation of code-switching in junior high school is a common practice since it brings an advantage to English teaching and learning process.
\end{abstract}

Keywords: code-switching, English learning, sociolinguistics

\section{INTRODUCTION}

Nowadays, bilingualism and multilingualism cannot be avoided. It is the effect of intensive communication in the society. Most countries are bilingual or multilingual, depending on how many languages they use. According to Trudgill (1992, p. 13), bilingualism is the ability of an individual to speak two or more languages. However, some writers define bilingualism as individuals who have a native command of more than one language. People are bilinguals if they master or use two languages in social communication. Webster Dictionary (in Adams, 2004, p. 3) defines bilingual as having or using two languages especially as spoken with the fluency characteristic of a native speaker; a person using two languages especially habitually and with control like that of a native speaker'. Meanwhile, multilingual are those who speak more than two languages (Myers-Scotton, 2006, p. 2). Perhaps only a few people are monolingual. Myers-Scotton also states that more people in the world are bilinguals than monolinguals (p.2).

Bilingualism is found in many situations, informal interaction (e.g. teaching and learning process) and informal situation (e.g. music concert). Most people in our society have been infected by the phenomena that bilingual community cannot be avoided. Bilinguals speak two languages on communication rather than using only one language. They change the language whenever they want to. For instance, a speaker changes the language from English into Indonesian or Indonesian into English. 
English is a language that most people use in the world to communicate. The use of English in this global era is very crucial. It is used and needed in every sector such as politics, economics, and education. In education, English becomes one of the languages taught to students in the world. In Indonesia, English becomes the main foreign language taught in schools besides Mandarin, Japanese, German, and Arabic. In addition, English is taught to the students in elementary school, junior high school, senior high school, and university. In junior high schools and senior high schools, English is one of the subjects which is tested in the national exam. As a consequence, English has more time allocation than other subjects.

In teaching English as a foreign language in Indonesia, teachers must use English as the language of instruction. In fact, there are phenomena wherein teachers use not only English as their language of instruction in the class but also Indonesian language and sometimes use a local language. Both teachers and students use English, Indonesian, and local language alternately in the classroom.

In this research, the researcher wanted to investigate those phenomena in English teaching and learning process in SMP Negeri 4 Surakarta. The researcher is expected to describe widely and clearly of the use of more than one language alternately in teaching English in the classroom. The result of the observation and interview shows that the teacher uses English as the language of instruction but sometimes they also switch from English to Indonesian or regional dialect. The phenomena on changing and/or switching one language to another are called codeswitching. The term code-switching is defined by Edward (1994) as "where individual change

RESEARCH METHOD language frequently, often within one sentence" (p. 3).

The reason that motivates the teacher to do code switching from English to Indonesian or regional dialect varies depending on the situation. Different situations possess different factors or reasons as well. Some reasons are that students are noisy, getting bored, and do not know the meaning of words or sentences. The teacher does something to solve the problem, such as making a joke, giving emphasis to the material, warning the students by raising the voice and translating the material to Indonesian.

This teacher's code-switching in English classroom is very useful. The students can have a better understanding of the material. Liebscher and Dailey-O'Cain (in Youkhana, 2010 , p. 5) suggest that teachers should see code-switching as an advantage and that the use of L1 (first language) is good and meaningful in order to encourage L2 acquisition. Indeed, there have been some debates among researchers that the teacher's code-switching in teaching and learning process has a positive and negative effect on the foreign language learning.

Duff and Polio (in Jingxia, 2010, p. 12), discovered that the teachers switched to the L1 mainly to explain grammar, to manage the class and maintain discipline, to index a stance of empathy or solidarity towards students, to translate unknown vocabulary items, and to help students when they have problems of understanding. All of those purposes of codeswitching is aimed to make the teacher can reach the purpose of teaching and learning process. Therefore, this research is aimed to know more and investigate the motivations, the types, and the functions of teacher's codeswitching in English language learning class.

The research was conducted using a qualitative method in the form of case study. 
According to Sturman (in Bassey, 1999, p. 26), a case study is a generic term for the investigation of an individual, group or phenomenon. This method is considered appropriate since this study attempts to have an in-depth investigation of the phenomena of teacher's code-switching in English teaching and learning process in SMP Negeri 4 Surakarta.

The data in this research are teachers' utterances, students' utterances, and interview statements. Those data are obtained from observation in three class es (VII.A, VII.B, and VII.C) and interview with the teacher and students of three classes. In analyzing the data, the researcher uses the Interactive model by Miles and Huberman (1994) who proposes three steps of data analysis, i.e. data reduction, data display, conclusion drawing/verification. The data were transcribed, organized, classified, categorized, and code. After that, the data were displayed, analyzed and verified to find the final conclusion. To know the validity of the data, the researcher proposed the data and consult to the lecturer.

\section{RESEARCH FINDINGS DISCUSSION}

\section{The Types of Code Switching}

There are two types of code-switching employed by the teacher, i.e. situational and metaphorical code-switching. It matches with Wardhaugh (2000, p.104) who describes two kinds of code-switching, i.e. situational and metaphorical code-switching. In line with Wardhaugh, Holmes (2001, p.35) also states that code-switching is classified into two types, namely situational and metaphorical codeswitching. Furthermore, Gumperz (1976) in Cantone (2007, p.59) distinguishes between the situational code-switching (which concerns the situation the speakers are exposed to), and metaphorical code-switching (which implicates language choice in order to attain special communicative effects).

Situational code-switching is used by the teacher in the three classes. Situational code-switching is used when there is a change in interlocutor and topic. The change of topic and interlocutor/participant can have advantages but also disadvantages. The researcher finds that the change of topic/interlocutor causes a positive effect in some situation. In teaching English, the teacher usually changes the interlocutor to give feedback to students' question and test students understanding of the material so that the students can understand the material well and the teacher can know the level of students' English comprehension. The disadvantage is when it becomes a distraction and disturb teaching process such as when someone enters the class in the middle of the teaching process and call for the chairman of the class. Those situations become a distraction to the teaching and learning process, as students lost their focus and the teacher re-explain the material, which is time-consuming.

The next type is metaphorical codeswitching. Metaphorical code-switching is used by the teacher in all classes observed. The researcher finds that teacher's metaphorical code-switching is used to change the situation and create a positive effect on students. The positive effect includes when the teacher can control the students, the students focus to teacher explanation, teachers know the students level of understanding the material, students understand the material and the lesson goal is reached by the teacher. 
Table 1. The Proportion of types of code-switching in three classes

\begin{tabular}{|c|c|c|c|c|c|c|}
\hline \multirow[t]{2}{*}{ No } & \multirow[t]{2}{*}{ Class } & \multicolumn{2}{|c|}{ Situational } & \multicolumn{2}{|c|}{ Metaphorical } & \multirow[t]{2}{*}{$\mathbf{S}><\mathbf{M}$} \\
\hline & & Number & Percentage & Number & Percentage & \\
\hline 1 & VII.A & 8 & $38.10 \%$ & 39 & $36.11 \%$ & $\mathrm{~S}<\mathrm{M}$ \\
\hline 2 & VII.B & 8 & $38.10 \%$ & 34 & $31.48 \%$ & $\mathrm{~S}<\mathrm{M}$ \\
\hline 3 & VII.C & 5 & $23.80 \%$ & 35 & $32.41 \%$ & $\mathrm{~S}<\mathrm{M}$ \\
\hline & Total & 21 & $100 \%$ & 108 & $100 \%$ & \\
\hline
\end{tabular}

The table 1. above shows that the occurrences of situational and metaphorical code switching in each class is different. In the findings the occurrences in VII.A there are 8 data of situational code-switching and 39 data of metaphorical code-switching. Second, In VII.B there are 8 data of situation codeswitching and 34 data of metaphorical codeswitching. Third, In VII.C there are 5 data of situational code-switching and 35 data of metaphorical code-switching. So, it shows that metaphorical code-switching has more frequency than situational code-switching in all classes.

\section{Teacher's motivation on Using Code- Switching in English Teaching and Learning Process.}

According to the observation and interview, the researcher finds that there are six motivations of teacher employing code switching in three classes, i.e. (1) the heterogeneous level of students' competence in understanding the material, (2) the students failure to understand the teacher's explanation and instruction if teacher using English, (3) the easy of using L1 to communicate with students, (4) unexpected external distractions, (5) the students' failure to understand teacher's question and correction, (6) the students' poor English competence and vocabulary master.

The first teacher's motivation is the heterogeneous level of students' competence in understanding the material. This motivation is related to students' English proficiency which becomes the main factor that triggers teacher to use code-switching. The students' English proficiency in this study is in the level of good which affects the ability of students in understanding the material. However, some of the students have low English proficiency and they need the explanation from the teacher in L1/Indonesian. In line with Tien and Liu (2000), who states that students with a low proficiency of target language can have a better understanding when the first language is used. So, it shows that the explanation of teacher in the first language is needed to make students understand what teachers' said.

The second teacher's motivation is the student's failure to understand the teacher's explanation and instruction if teacher using English. It happens because of the differences between English and Indonesian, and the explanation of the teacher that is too fast. Those points make it hard for the students to understand the teacher's said and codeswitching is required to solve the problem. The efficient way is the teacher has to use L1/Indonesian to make the students understand the teacher's explanation and instruction. It is supported by Cook $(2000,2011)$ in Jingxia (2010) who suggested that teachers should resort to the $\mathrm{L} 1$ if it is apparent using the TL would be inefficient and cause problems for the students

The third teacher's motivation is easy of using L1 to communicate with students. This point is in line with Bista (2010, p. 13) finding which 
stated $23 \%$ of the participants in his study responds that it is easier to speak in their own language than to speak in English. In the findings, this point happens when the teacher praises the students' works/performance, motivating student, and building close relationship between the teacher and the students. It can be concluded that the teacher used code-switching to reach some purposes.

The fourth teacher's motivation is unexpected external distractions. In the findings, the external distraction includes when someone enters the class in the middle of the teaching process, a call for chairman of the class, and there are also students who come late and enter the class when the teacher is explaining the material. The situation is the teacher used English to explain the material to students and suddenly there is an external distraction that makes student switch the code into Indonesian to respond it. An external distraction is something that cannot be avoided by the teacher and can bring a negative effect in a low of students' focus. So, the teacher has to be ready to respond it and decreasing the negative effect.

The fifth teacher's motivation is the students' failure to understand teacher's question and correction. The researcher finds that there is a situation in which some students confused about the question delivered by the teacher and their answer is wrong. That situation triggers the teacher to switch the code to repeat the question and correct the mistakes in L1/Indonesian so that the students clearly understand the question and finally can answer it. Also, the students understand the correct answer to the question so that there is no misunderstanding about it. As Bista (2010, p. 13) states there are $14 \%$ participants said that the reason they code switched was to avoid misunderstanding when they did not know the English equivalent.

The sixth teacher's motivation is the students' poor English competence and vocabulary master. It corresponds to Bista (2010, p. 14) that $14 \%$ of the participant is unfamiliar with the similar words in English. This point is related to the importance of the material and the vocabulary mastered by students. Obviously, the level of vocabulary master is good at the level of grade VII. In finding, the students don't understand about new words/sentences such Indonesia's big day (youth pledge day), a detail and long audio explanation from the native. That situation trigged teacher to use code-switching. However, in some cases, the teacher intentionally translates what they said to make the student easily understand the material and can have a fast response to it.

There are some conditions in the classroom underlying the teacher's motivation on using code-switching. It can be said that those conditions lead the teacher to use codeswitching or the teacher used code-switching in those conditions. Those conditions are revealed through classroom observation in three classes (VII A, VII B, VII C). The list of conditions that leads teacher on using code switching are as follows: (1) the students are noisy/the students do not focus, (2) the students do not do what the teachers said/instructed immediately, (3) the students are not active, (4) the students do not understand the material or teacher's utterance, (5) the concept/material being explained is important/difficult, (6) when translating words/phrases/sentences, (7) there is something funny in the class, (8) when the teacher is building close relationship between the teacher and the students, (9) when the teacher is giving instruction, (10) when the teacher is correcting students' mistakes/error, (11) when the teacher is testing students' comprehension, (12) when the teacher is praising the students' works/performance, (13) when the teacher is changing 
addressee/interlocutor, (14) when the teacher is checking for the students' understanding. The correlation between those points is that the situation/condition in each class raises some motivations of the teacher to do code- switching. The correlation between teacher's reason and the situation/condition when the teacher does code-switching is presented in table 2. below.

Table 2. The correlation between teacher's motivation and condition when teacher do codeswitching

\begin{tabular}{|c|c|c|}
\hline No & Situation which motivates teacher & Teacher's motivation \\
\hline 1 & $\begin{array}{l}\text { The students are noisy/the students do not } \\
\text { focus }\end{array}$ & $\begin{array}{l}\text { a. The student's failure to understand the teacher's } \\
\text { explanation and instruction if teacher using English }\end{array}$ \\
\hline 2 & $\begin{array}{l}\text { The students do not do what the teachers } \\
\text { said/instructed immediately }\end{array}$ & $\begin{array}{l}\text { a. The student's failure to understand the teacher's } \\
\text { explanation and instruction if teacher using English }\end{array}$ \\
\hline 3 & The students are not active & $\begin{array}{l}\text { a. The heterogeneous level of students' competence } \\
\text { in understanding the material } \\
\text { b. The student's failure to understand the teacher's } \\
\text { explanation and instruction if teacher using English }\end{array}$ \\
\hline 4 & $\begin{array}{l}\text { The students do not understand the material or } \\
\text { teacher's utterance }\end{array}$ & $\begin{array}{l}\text { a. The heterogeneous level of students' competence } \\
\text { in understanding the material } \\
\text { b. The student's failure to understand the teacher's } \\
\text { explanation and instruction if teacher using English }\end{array}$ \\
\hline 5 & $\begin{array}{l}\text { The concept/material being explained is } \\
\text { important/difficult }\end{array}$ & $\begin{array}{l}\text { a. The heterogeneous level of students' competence } \\
\text { in understanding the material } \\
\text { b. The student's failure to understand the teacher's } \\
\text { explanation and instruction if teacher using } \\
\text { English }\end{array}$ \\
\hline 6 & $\begin{array}{l}\text { When the teacher is translating } \\
\text { words/phrases/sentences }\end{array}$ & $\begin{array}{l}\text { a. The students' poor English competence and } \\
\text { vocabulary master. }\end{array}$ \\
\hline 7 & There is something funny in the class & $\begin{array}{l}\text { a. The easy of using L1 to communicate with } \\
\text { students. }\end{array}$ \\
\hline 8 & $\begin{array}{l}\text { When the teacher is building a close } \\
\text { relationship between the teacher and the } \\
\text { students }\end{array}$ & $\begin{array}{l}\text { a. The easy of using L1 to communicate with } \\
\text { students. }\end{array}$ \\
\hline 9 & When the teacher is giving instruction & $\begin{array}{l}\text { a. The student's failure to understand the teacher's } \\
\text { explanation and instruction if teacher using } \\
\text { English. }\end{array}$ \\
\hline 10 & $\begin{array}{l}\text { When the teacher is correcting students' } \\
\text { mistakes/error }\end{array}$ & $\begin{array}{l}\text { a. The students' failure to understand teacher's } \\
\text { question and correction. }\end{array}$ \\
\hline 11 & $\begin{array}{l}\text { When the teacher is evaluating students } \\
\text { works/performance }\end{array}$ & $\begin{array}{l}\text { a. The students' failure to understand teacher's } \\
\text { question and correction }\end{array}$ \\
\hline 12 & $\begin{array}{l}\text { When the teacher is praising the students' } \\
\text { works/performance }\end{array}$ & $\begin{array}{l}\text { a. The easy of using } \mathrm{L} 1 \text { to communicate with } \\
\text { students. }\end{array}$ \\
\hline 13 & $\begin{array}{l}\text { When the teacher is changing } \\
\text { addressee/interlocutor }\end{array}$ & a. Unexpected external distractions. \\
\hline
\end{tabular}




\begin{tabular}{l|l|l}
\hline 14 & $\begin{array}{l}\text { When the teacher is checking the students' } \\
\text { understanding }\end{array}$ & $\begin{array}{l}\text { a. The students' failure to understand teacher's } \\
\text { question and correction. } \\
\text { b. The easy of using L1 to communicate with } \\
\text { students. }\end{array}$ \\
\hline
\end{tabular}

\section{The Functions of Teacher's Code-Switching in English Teaching and Learning Process.}

Stated by Cameron (2001), there are ten functions on the use of teachers' first language in classroom: explaining aspects of the foreign language, translating words or sentences, giving instructions, checking understanding of concept/talk/text/instructions, eliciting language, focusing pupils' attention, testing, talking about learning, giving feedback, disciplining and control, informal/ friendly talk with pupils.

In general, most of the functions found have the same classification as Cameron, except eliciting language. There are nine functions of code switching found in three classes. The occurrence/frequency of each function is different. To make it clear, the following is a table of the frequency of the functions of code-switching in each class.

Table 3. The Proportion of the Function of Code-Switching in three classes

\begin{tabular}{|c|c|c|c|c|c|c|c|}
\hline \multirow[t]{2}{*}{ No. } & \multirow[t]{2}{*}{ Functions } & \multicolumn{2}{|c|}{ VII.A } & \multicolumn{2}{|c|}{ VII.B } & \multicolumn{2}{|c|}{ VII.C } \\
\hline & & Datum & $\%$ & Datum & $\%$ & Datum & $\%$ \\
\hline 1 & $\begin{array}{l}\text { Explaining } \\
\text { concept }\end{array}$ & 14 & $35.90 \%$ & 9 & $23.08 \%$ & 16 & $41.02 \%$ \\
\hline 2 & $\begin{array}{l}\text { Giving } \\
\text { instruction }\end{array}$ & 14 & $38.89 \%$ & 7 & $19.44 \%$ & 15 & $41.67 \%$ \\
\hline 3 & Translating & 8 & $44.45 \%$ & 4 & $22.22 \%$ & 6 & $33.33 \%$ \\
\hline 4 & $\begin{array}{l}\text { Motivating } \\
\text { students/drawing } \\
\text { students' } \\
\text { perception }\end{array}$ & 1 & $20 \%$ & 3 & $60 \%$ & 1 & $20 \%$ \\
\hline 5 & Giving feedback & 8 & $40 \%$ & 7 & $35 \%$ & 5 & $25 \%$ \\
\hline 6 & $\begin{array}{l}\text { Checking } \\
\text { understanding }\end{array}$ & 7 & $33.33 \%$ & 10 & $47.62 \%$ & 4 & $19.05 \%$ \\
\hline 7 & $\begin{array}{l}\text { Disciplining and } \\
\text { controlling }\end{array}$ & 2 & $25 \%$ & 3 & $37.5 \%$ & 3 & $37.5 \%$ \\
\hline 8 & Testing students & 9 & $52.94 \%$ & 4 & $23.53 \%$ & 4 & 23.53 \\
\hline 9 & Socializing & 1 & $16.67 \%$ & 3 & $50 \%$ & 2 & $33.33 \%$ \\
\hline
\end{tabular}

The table 3. shows that that the most frequent code-switching functions used by the teacher in teaching English are: (1) explaining a concept (2) giving instruction and (3) checking understanding. Those three functions done by the teacher have a positive effect on the students and the teaching process. First, in doing code switching when explaining the material, the students can easily understand the material, raise students' English comprehension and students' English proficiency, and it also saves time to make students understand quickly by using L1/Indonesian. Second, the teacher employs code-switching to give an instruction such as to answer the question and to change the way 
students read the time. This function becomes a time saving, it enables students to respond to the teacher said quickly. Third, the use of code switching when checking students understanding is to enable students to understand the questions and respond. The teacher can identify the level of students' English proficiency and what she will do in the next step.

\section{CONCLUSION, IMPLICATION, AND SUGGESTION}

Based on the finding and the discussion, there are two types of code-switching employed by the teacher, i.e. Situational codeswitching and Metaphorical code-switching. Situational code-switching is identified by a change of topic and interlocutor/participant. While metaphorical code-switching is used to change a situation, signal quotation, mark emphasis, indicate jokes, show the relationship between participants, show the speakers thought, and show the speaker's position in a group. In addition, the frequency of two types of code-switching is different. Situational code-switching in the three classes occurs in 21 data (16.28\%) out of 129 data. Metaphorical code-switching in the three classes occurs in 108 data $(83.72 \%)$ out of 129 data. It can be said that Metaphorical code-switching is more often used by the teacher rather than Situational code-switching.

The next point is teacher's motivation on using code-switching or factors that trigger teacher to do code-switching. Based on the finding and discussion, there are six motivations to use code switching by teacher in three classes: (1) the level of students in understanding the material is heterogeneous, (2) the students may not understand the teacher's explanation and instruction if teacher using English, (3) it is more comfortable and easier using L1 to communicate with students when communicating in purpose, (4) there is an external distraction that makes teacher uses L1, (5) the students get confused and sometimes do not get the point when teacher tests the students or corrects students' mistakes using English, (6) the students may not understand about words, sentences, and technical term of English and have to translate it.

Then, there are nine functions of codeswitching realized by the teacher in the three classes (VII.A, VII.B, VII.C) in SMP Negeri 4 Surakarta. The functions are explaining a concept, giving instruction, translating, motivating students, drawing students' perception, giving feedback, checking understanding, disciplining and controlling, testing students, and socializing. Furthermore, explaining a concept, giving instruction, and checking students' understanding is the most code switching's function used by the teacher.

In summary, the implementation of Code-switching can be used as teacher's strategy on teaching English and brings an advantage to English teaching and learning process. Code-switching can also be modified with another teaching method to make a betterment in English teaching and learning process such as solving the communication gap between teacher and students, to cope with students' low understanding in the teachinglearning process, and to help students' vocabulary become richer.

The researcher proposes some suggestion related to the use of code-switching employed by a teacher in English teaching and learning process. First, the English teacher, the English teacher should have background knowledge of code-switching, especially bilingual education. The teacher also has to concern with the characteristic of learners, the class culture, the class condition, and the goal that will be achieved in the learning process so that the teacher can use code-switching in effectively in teaching English as a foreign 
language. Second, the students, the students have to be more aware of using their L1 (Indonesian language) on English learning process so that they do not disturb their teacher or classmate when using English as a foreign language learning. The last, the other researcher, other researcher is expected to investigate more about the occurrences of code-switching.

\section{BIBLIOGRAPHY}

Adams, J. N. ( 2004). Bilingualism and the Latin Language. London: Cambridge University Press.

Bassey, M. (1999). Case Study Research in Educational Settings. Buckingham: Open University Press.

Bista, K. (2010). The factor of Code Switching among Bilingual English Students in the University Classroom: A Survey. English for Specific Purposes World, 9(29), 1-19.

Cameron, L. (2001). Teaching languages to young learners. London: Cambridge University Press.

Cantone, K.F.(2007). Code Switching in Bilingual Children. Berlin: Springer

Edward, J. (1994). Multilingualism. London and New York: Routledge.
Holmes, Janet. 1997. An Introduction to Sociolinguistics. London: Addison Wesley Longman Inc.

Jingxia, L. (2010). Teacher's code-switching to the L1 in EFL classroom. The_Open Applied Linguistics Journal, 3, 10-23.

Miles, Matthew B., \& Hubermand, A. Michael. (1994). Qualitative Data Analysis. London: Sage Publication Ltd.

Myers-Scotton, Carol. (2006). Multiple Voices: An Introduction to Bilingualism. Oxford: Blackwell Publishing Ltd.

Trudgill, P. (1992). Introducing language and society. London: Penguin Books Ltd.

Wardhaugh, R. (2000). Introduction to Sociolinguistics (3rd ed). Oxford: Blackwell Publishing Ltd.

Youkhana, S. (2010). Code Switching in the Foreign Language Classroom. Retrieved on January 15, 2015, from http://www.divaportal.org/smash/get/diva2:404799/F ULLTEXT02.pdf 